UNITED NATIONS CONFERENCE ON TRADE AND DEVELOPMENT

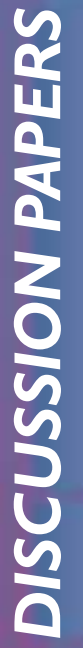

POLICY SPACE: WHAT, FOR WHAT, AND WHERE? 



\title{
POLICY SPACE: WHAT, FOR WHAT, AND WHERE?
}

\author{
Jörg Mayer
}

No. 191

October 2008

\begin{abstract}
Acknowledgement: The paper draws on the author's contributions to UNCTAD's Trade and Development Report 2006. The author is grateful to Kevin Gallagher, Gerry Helleiner, Dieter Hesse, Detlef Kotte, Andrew Mold, Sheila Page, Ugo Panizza, Ken Shadlen, Adrian Wood, and participants of a Geneva Trade and Development Workshop for helpful comments and suggestions, and an anonymous referee for an opinion, on an earlier draft. The opinions expressed are solely those of the author and do not necessarily reflect the views of UNCTAD or its Member States. Any citation of this paper should ascribe authorship to the author and not to UNCTAD.
\end{abstract}


The opinions expressed in this paper are those of the author and are not to be taken as the official views of the UNCTAD Secretariat or its Member States. The designations and terminology employed are also those of the author.

UNCTAD Discussion Papers are read anonymously by at least one referee, whose comments are taken into account before publication.

Comments on this paper are invited and may be addressed to the author, c/o the Publications Assistant, Macroeconomic and Development Policies Branch (MDPB), Division on Globalization and Development Strategies (DGDS), United Nations Conference on Trade and Development (UNCTAD), Palais des Nations, CH-1211 Geneva 10, Switzerland (Telefax no: (4122) 9170274/Telephone no: (4122) 9175896). Copies of Discussion Papers may also be obtained from this address.

New Discussion Papers are available on the UNCTAD website at http://www.unctad.org. 


\section{Contents}

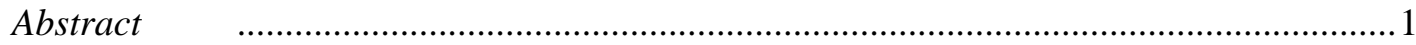

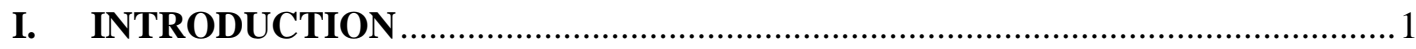

II. NATIONAL POLICY SPACE OF AN INTEGRATING ECONOMY ..................

III. LINKING POLICY INSTRUMENTS AND TARGETS IN AN

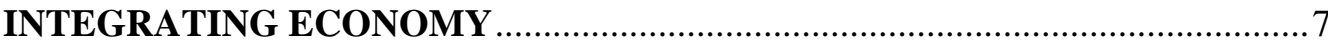

A. Macroeconomic and exchange-rate policies …..................................................... 9

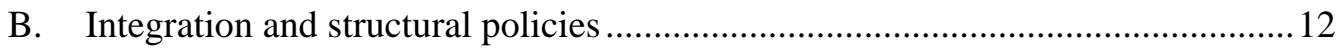

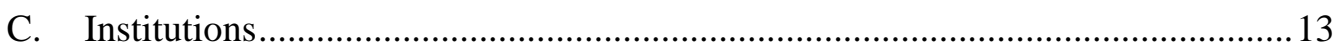

IV. NATIONAL AND INTERNATIONAL MEASURES TO ENLARGE

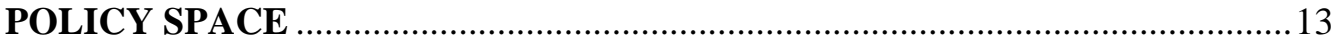

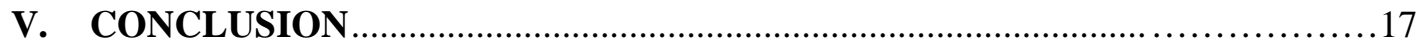

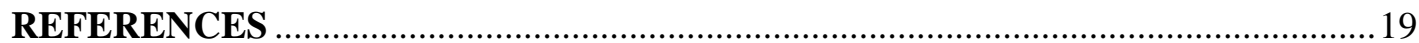

Figure 1: Instrument-target relationships from a heterodox perspective........................9

Table 1: Constraints on developing countries’ policy space and measures

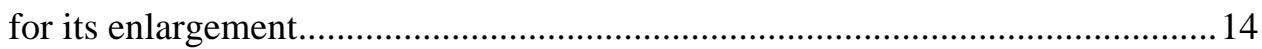





\title{
POLICY SPACE: WHAT, FOR WHAT, AND WHERE?
}

\author{
Jörg Mayer \\ (UNCTAD)
}

\begin{abstract}
The paper examines how developing countries can use existing policy space, and enlarge it, without opting out of international commitments. It argues that: (i) a meaningful context for policy space must extend beyond trade policy and include macroeconomic and exchange-rate policies that will achieve developmental goals more effectively; (ii) policy space depends not only on international rules but also on the impact of international market conditions and policy decisions taken in other countries on the effectiveness of national policy instruments; and (iii) international integration affects policy space through several factors that pull in opposite directions; whether it increases or reduces policy space differs by country and type of integration.
\end{abstract}

\section{INTRODUCTION}

The role of national policies in economic development has long been debated. Much of the current debate concerns the concept of "policy space" and focuses on the tension between international economic integration and the autonomy available to nation states to pursue policies that effectively support their economic development. This tension arises from the dilemma of "how to keep the manifold benefits of extensive international economic intercourse free of crippling restrictions while at the same time preserving a maximum degree of freedom for each nation to pursue its legitimate economic objectives", as noted by Cooper (1968: 5).

Recent concern about the tension between international integration and national policy autonomy mainly relates to two factors. First, the policy agenda which many developing countries pursued during the 1980s and 1990s did not result in the desired acceleration of economic development (e.g. World Bank, 2005). Second, the greatly increased internationalization of markets and the associated stronger impact of foreign factors on national development have in many instances weakened the effectiveness of domestic policies. These factors combined triggered a debate on the commonalities of successful growth strategies that could frame the conduct of economic policies and the desirability of more proactive policies in development strategies (UN Millennium Project (Sachs Report), 2005; World Bank, 2005; United Nations, 2007; Commission on Growth and Development (Spence Report), 2008). This debate remains unsettled, but it generally emphasizes "that there is no universal set of rules" and "that growth entails more than the efficient use of resources" (World Bank, 2005: xii and 10). 
However, it is often perceived that a desire to go beyond attaining the efficient use of resources and pursue more proactive policies is faced with a reduced number of effective policy instruments. For instance, the outcome of the Uruguay Round (UR) of multilateral trade negotiations has extended the scope of multilateral disciplines to include rules that impinge directly on domestic policies. This may explain why much of the debate on policy space is confined to trade policy and concerned with how the UR agreements restrict the sovereignty of nation states to make their own policy decisions (e.g. Gallagher, 2005; Hamwey, 2005; Abugattas and Paus, 2006; Brown and Stern, 2006; DiCaprio and Gallagher, 2006; Kumar and Gallagher, 2007). Most of these studies voice the concern that UR disciplines prevent developing countries from following the most effective development policies. This may be interpreted as suggesting that developing countries could increase their current policy space only by opting out of at least some of their international commitments.

This paper takes a different perspective. It examines how developing countries can effectively use existing national policy space, and indeed enlarge it, without opting out of international commitments. ${ }^{1}$ Its five main arguments are: (i) to be meaningful and pro-development, the context for policy space must extend beyond trade policy and include the many non-trade (particularly macroeconomic and exchange-rate) policies that will achieve developmental goals more effectively; (ii) policy space depends not only on international rules; rather, in a globalized world it also depends on the impact of international market conditions and policy decisions taken in other countries on the effectiveness of national policy instruments; (iii) international integration affects policy space through several factors that pull in opposite directions; whether it increases or reduces policy space differs by country and type of integration; (iv) policy makers who choose to pursue more proactive policies and broad development objectives which privilege real economic variables (e.g. real output and income growth) require instruments that allow to: (a) correct for market and government failures; (b) manage boom-bust cycles; (c) deal effectively with external shocks; and (v) while the UR agreements have introduced restrictions, most of the policy space required to pursue proactive development policies is available, and it could be further enlarged by tightening disciplines in international monetary and financial relationships.

The theory of economic policy, dating back to Tinbergen (1952), forms the methodological framework of the following examination. While this approach may not be applicable as a blueprint for contemporary policy-making (van Velthoven, 1990), its basic concepts remain useful. Thinking of policy-making in terms of instruments, targets and a model that describes the relationship between targets, instruments and other variables is widespread in public debate and allows consideration of the operational content of the concept of policy space.

The next section aims at clarifying what is meant by the concept of policy space. Section 3 examines for what purposes a broad range of policy instruments may be required if policy makers choose to pursue more proactive development strategies. It maps the linkages between instruments and targets so as to determine broad instrument-target assignments in such a strategy. Section 4 uses this mapping to identify areas where actions at the national and international levels might allow developing countries to use their existing policy space more effectively and to increase it without opting out of international commitments. Section 5 concludes.

Although not within the scope of this paper, it should be noted that the mere fact of having policy space does not imply that it is always put to good use. Some developing countries have used their policy space effectively, and they have been rewarded with accelerated development, while others have been less able to capitalize on existing policy autonomy. Effective use of policy space requires policymakers to have a vision of where they want to

\footnotetext{
1 Thus, this paper complements discussions on improving WTO rules on special and differential treatment for developing countries (see, for example, UNCTAD, 2006: 223-225).
} 
take an economy. This, in turn, necessitates the formulation of a national development strategy that has a clear understanding of local capabilities, constraints and opportunities, and that identifies clear objectives, spells out how policy instruments will be deployed to attain them, and establishes effective monitoring mechanisms to determine whether policy targets are being met. Widespread scepticism about the institutional capacity of some countries to manage a proactive development strategy cannot be ignored. Part of this scepticism is clearly justified, given the poorly performing institutional set-ups in a number of countries.

It may be useful to emphasize also what the paper is not intended to do. First, it provides no new theoretical insights on consistent policy making. Rather, the paper draws on the literature on policy making in developing countries (particularly Rodrik, 2004; and Stiglitz et al., 2006) and examines how the type of integration proposed there relates to the policy-space debate. The paper focuses on Rodrik (2004) and Stiglitz et al. (2006) because the integration strategy proposed by these authors implies a much more proactive role of economic policies than those suggested by others. Hence, the findings of this paper may be considered the outcome of an extreme case scenario. Second, the paper does not present a country case study which would be the only way to identify with reasonable precision how the effectiveness of a feasible set of policies is influenced by the structure of the domestic economy, a given global economic situation, and by a given domestic and global institutional environment. While this would be an interesting area for further research, such an assessment is necessarily determined by country- and time-specific factors. ${ }^{2}$

\section{NATIONAL POLICY SPACE OF AN INTEGRATING ECONOMY}

The theory of economic policy - initiated by Tinbergen (1952), elaborated from a macroeconomic interdependence perspective by Cooper (1968) and Bryant (1980), and recently also used in the policy-space debate by UNCTAD (2006) and Akyüz (2007) - has been an important basis for addressing the effectiveness of policies in the evolution of a national economy. ${ }^{3}$ In spite of the many arguments ${ }^{4}$ against applying that theory as a blueprint, both policymakers and economists who provide policy advice generally adopt, explicitly or implicitly, its basic ingredients. Those ingredients are: (i) a set of instruments that are subject to direct control by policymakers; (ii) a set of targets that describe the evolution of the national economy; and (iii) a model, which describes the economic relationships between instruments and targets, as well as the choices available to policymakers to attain desired values of the targets by applying specific instruments. Given that a multitude of instruments have an impact on the chosen targets and that often there are significant time lags before such impacts become measurable, it is useful also to include a number of intermediate targets in the model in addition to a small number of ultimate target

\footnotetext{
2 A possible methodology for such an assessment could be "growth diagnostics" as explained by Hausmann, Klinger and Wagner (2008).

${ }^{3}$ The theory of economic policy only addresses what Tinbergen (1952) called "quantitative” economic policy, which is distinct from the "qualitative" framework in which policymakers operate. The latter describes a country's economic and political institutional arrangements that have a strong impact on incentives and on the behaviour of both policymakers and individuals, and thus on the structural characteristics of instrument-target relationships.

${ }^{4}$ Van Velthoven (1990) discusses four major criticisms: (i) rational expectations, suggesting policy ineffectiveness; (ii) the Lucas critique, suggesting that the coefficients of the model describing instrument-target relationships will in part reflect the specific combination of instruments applied during the period over which they are estimated, and thus need not be stable; (iii) information constraints and decision costs, which further reduce the certainty with which a given set of instruments can attain the targets that define a specific level of social welfare; and (iv) public choice issues, which question whether public sector decision-making is an adequate reflection of citizens' preferences.
} 
variables. ${ }^{5}$ There are two important rules of the theory of economic policy: (i) the number of policy instruments must be at least as great as the number of targets if all targets are to be attained; and (ii) in case of trade-offs between target variables, policymakers must use a social welfare function to decide which combination of instruments maximizes the degree to which a consistent set of targets can be attained.

Policymakers in closed economies have full sovereign command over policy instruments, but they may not be able to control specific policy targets effectively. First, potential trade-offs in the effectiveness of different instruments, as well as in the objectives sought, make it difficult to combine the available instruments in a way that would enable all targets to be attained simultaneously (van Velthoven, 1990). Such trade-offs exist in many policy areas, for example between full employment and price stability, growth and income distribution or, more generally, between efficiency and equity. Second, instruments can be used only within specific boundaries (Bryant, 1980: 173). For example, there is a limit to how far nominal interest rates can be lowered. Third, the relationships between policy instruments and targets are often unstable, and knowledge and information about these relationships are usually incomplete. This problem is particularly acute in developing countries where policy aims at achieving structural change and thus involves a continuous adaptation of targets, instruments and behavioural relations rather than a routine use of a given instrument-target relationship. This need for constant adaptation makes it desirable to have available as many effective policy instruments as possible (Cooper, 1968: 153-154).

To analyse instrument-target relationships in an internationally integrated economy, it is useful to distinguish de jure sovereignty, which involves the formal authority of national policymakers over policy instruments, and de facto control, which involves the ability of national policymakers to effectively influence specific targets through the skilful use of policy instruments (Cooper, 1968: 4; Bryant, 1980: 149-150). On this basis, national policy space may be defined as the combination of de jure policy sovereignty and de facto national policy autonomy.

This distinction suggests that international economic integration affects national policy space through several forces that pull in opposite directions. The process of integration into the global economy restricts national policy space in terms of both a reduction in the number of available instruments as a result of legal commitments to international rules and practices (i.e. constraints on de jure policy sovereignty), and in terms of the reduced effectiveness of macroeconomic instruments (i.e. constraints on de facto policy autonomy). At the same time, integration enlarges national policy space in terms of de facto control because (i) multilateral rules and disciplines enable a coordinated response to cross-border disturbances and prevent policymakers in countries that can have a disproportionately large impact on the evolution of other economies from adopting discriminatory or beggar-thy-neighbour policies, thus restoring part of the effectiveness of domestic instrument-target relationships in internationally less influential countries; and because (ii) integration into a larger market increases the effectiveness of many structural policies, particularly those whose effectiveness strongly depends on scale economies or the disciplines of international competition. ${ }^{6}$

\footnotetext{
${ }^{5}$ For example, controlling investment-to-GDP ratios or technology and education levels can be intermediate targets for achieving income growth.

${ }^{6}$ The conceptual framework presented by Hamwey (2005) and adopted by Abugattas and Paus (2006) distinguishes external and internal policy space. The former is delineated by international agreements and market expectations, while the latter is constricted by domestic institutional capabilities and resources that define the capacity of a country to implement development policies. A country's available policy space is thus confined to the overlapping of the two sets of policy space. The main drawbacks of Hamwey's framework are that it considers international rules exclusively as constraining, thus ignoring the protection that those rules provide against other countries' beggar-thy-neighbour policies, and that it ignores the fact that de facto integration can reduce national policy space with much the same effect as a loss of sovereignty through adherence to international rules.
} 
The workings of these different forces, which make policy space an issue of finding the right balance, can be considered more precisely as follows:

(1) Integration into international economic relationships weakens de facto control over national economic development by allowing foreign actions and conditions to influence national macroeconomic policy targets. ${ }^{7}$ This reduced effectiveness in the ability to control national policy targets is most prominent in monetary policy. As national money and capital markets are joined by international flows of funds, interest rates tend to converge across countries. This can create trade-offs between attaining internal or external targets. For example, in response to changes in international financial markets domestic policymakers may be compelled to change the level of the domestic interest rate because the relative difference in interest rates affects cross-border capital movements. However, such a change may result in an absolute level of the interest rate that is inappropriate for attaining domestic policy targets. Moreover, with an open capital account both the exchange rate and the interest rate are potential policy instruments, but only one of them can actually be employed independently. ${ }^{8}$

(2) Multilateral rules and disciplines, as well as commitments resulting from bilateral agreements, reduce de jure sovereign control over policy instruments. For example, the conditionality attached to assistance from the international financial institutions (IFIs) reduces the autonomy of governments to determine the size of public expenditures, and WTO agreements reduce the scope for Member States to impose trade-related performance requirements on the granting of subsidies to domestic manufacturers.

These two sources of external constraints on national policy space overlap and reinforce each other. On the one hand, integration into international markets reduces the number of instruments controlled by policymakers much in the way sovereignty is circumscribed by enhanced international rules and disciplines. On the other hand, international rules and disciplines weaken the influence of national policy instruments over national policy targets by promoting economic integration.

This weakening of sovereignty and of the effectiveness of national instruments over national targets must be weighed against the gains from integration into international markets and participation in the system of multilateral rules and disciplines.

(3) While de facto integration into international markets reduces the effectiveness of national macroeconomic policies, it can improve the effectiveness of many structural policies that are of crucial importance for developing countries. Increasing returns to scale on an industrywide basis and enhanced technological upgrading are the two main channels that, compared to policies in closed economies, make outward-oriented policies more effective in establishing competitive industries, thus improving the effectiveness of national sectoral and technology policies. For example, technological upgrading in developing countries often depends on the availability of foreign technologies embodied in imported capital goods, particularly during the initial stages of industrialization. Economic integration facilitates access to foreign technologies, and the foreign exchange earned from exporting alleviates the balance-ofpayments constraint. Both these mechanisms combine to reinforce the effectiveness of a country's sectoral and technology policies to build productive capacity and spur productivity growth. Regarding financial integration, access to international financial markets enable domestic firms to finance investment at internationally competitive conditions, which increases the effectiveness of national investment policies.

\footnotetext{
${ }^{7}$ Akyüz (2007), following Cooper (1968) and Bryant (1980), discusses the impact of openness on macroeconomic policy autonomy in a similar way.

${ }^{8}$ For the distinction between potential and actual policy instruments, see Bryant (1980: 13).
} 
(4) Multilateral rules and disciplines can also improve national policy effectiveness. ${ }^{9}$ According to Akyüz (2007: 8), "multilateral rules and disciplines are a form of global collective action whereby governments voluntarily agree to reduce sovereignty on a reciprocal basis by subjecting their policies in specified areas to certain rules in the expectation that such an action would lead to a net benefit”. Ideally, such a system would form a coherent set of multilateral arrangements. Its guiding principle would be to manage the interface between different national systems, rather than reducing national differences and establishing one omnipotent economic and legal structure.

Globalization provides an opportunity for policymakers in influential economies to use beggar-thy-neighbour policies. They may be tempted to employ commercial, macroeconomic or exchange-rate policies in pursuit of specific national objectives - such as attaining mercantilist goals or postponing the adjustment of internal or external imbalances - which reduce the effectiveness of national policy instruments in other countries. In the absence of multilateral disciplines and cooperation, retaliatory action by adversely affected countries could lead to disruptions in international economic relations that might leave all countries worse off.

Multilateral cooperation and disciplines can also help maximize global public goods. Countries might refrain from undertaking unilateral trade liberalization - for fear of adverse effects on their balance of payments and employment - even when they believe that doing so would bring efficiency gains. However, they might be willing to undertake multilateral trade liberalization because the principles of reciprocity and non-discrimination underlying multilateral rules give relatively weak countries better protection than they would be able to obtain on their own by negotiating bilateral agreements or staying out of any multilateral commitments altogether. As far as systemic stability in international money and finance is concerned, it is likely that emerging economies will remain vulnerable to currency and financial crises as long as the currencies of the major industrial countries remain subject to large gyrations. By contrast, macroeconomic policy coordination and multilateral monetary and financial disciplines that would ensure stable and well-aligned exchange rates among the key currencies would shield weaker and smaller economies from adverse impulses originating from monetary and fiscal policies in the major countries.

For global collective action to be acceptable to all parties, it must result from a bargaining process based on the full, equal and voluntary participation of all the parties concerned. However, there is a natural inclination, particularly by internationally powerful countries, to shape multilateral arrangements in a way that gives them maximum flexibility to pursue their own goals while restricting the degrees of freedom for others in areas of conflicting national interests. Countries that feel disadvantaged by the way multilateral rules and commitments are formulated and implemented can, in principle, choose not to participate in or leave the multilateral arrangements in question and conduct international relations on a bilateral basis. But countries with little power internationally (i.e. the vast majority of developing, as well as many developed countries) will not be well-advised to follow this route, because coercive action is likely to be even stronger in bilateral relationships with major economic and political powers.

To summarize, the tension between international economic integration on the one hand and the degree of autonomy available to a country to implement policies that effectively influence its economic performance on the other is governed by both its de facto integration into international markets and its de jure integration into supranational governance structures. How to determine the right balance between maintaining flexibility in national economic policy-making and reducing it through multilateral disciplines and collective governance remains a contentious issue. On the one hand, the absence of multilateral disciplines can

\footnotetext{
${ }^{9}$ This and the following three paragraphs partly follow Akyüz (2007).
} 
disrupt international economic relations and/or bias them in favour of those countries that wield substantial economic or political power. On the other hand, an increasing extension of legally binding external constraints on national economic policies, including multilateral rules and obligations established without the full participation of all countries concerned and biased against the interests of some groups of countries, would unduly impinge on the availability or effectiveness of national policy instruments.

However, there is no quantifiable single balance between multilateral disciplines and national policy autonomy that suits all countries or applies across all spheres of economic activity. The maturity of a country's institutional development, the sustainability of its external accounts, its economic size and pattern of domestic production will influence the impact of its international economic integration on the effectiveness of national policies. Similarly, at any level of economic development, a country's optimal degree of international integration is likely to differ across different spheres such as trade, investment, finance, labour and technology. For example, the existence of a functioning domestic financial market and previous integration into international goods markets are likely to be significant factors in determining the impact of a country's capital market integration on the effectiveness of its monetary and financial policies. Hence, whether international integration increases or reduces national policy space is an empirical question for each country and for each type of integration.

\section{LINKING POLICY INSTRUMENTS AND TARGETS IN AN INTEGRATING ECONOMY}

One difficulty in applying the instruments-targets approach to real-life policy-making is the limited knowledge about the incentive and behavioural structures of individuals, as well as the ways in which policymakers react to changes in the structure of the economy or to external shocks. Both these aspects, which may be considered as forming part of what Tinbergen (1952) called the "qualitative" framework of an economy, are highly location- and timespecific. Getting better knowledge of this qualitative framework is likely to be one element of “development as a discovery process” (Hausmann and Rodrik, 2003).

Another difficulty is the absence of a consensus on how the process of growth and development is generated and sustained, and how policy instruments and targets relate to each other in this process. Most development concepts consider stable and sustained real income growth to remain the most important target of economic policy in developing countries. ${ }^{10}$ But rival concepts embody significantly different analytical views with attendant controversies as to what targets policymakers should pursue, how best to describe instrument-target relationships, and how de facto and de jure international integration impact on the (effective) use of national policy instruments.

Given these differences, it is useful as a first step to map, if only in an illustrative manner, what instrument-target relationships try to attain in different policy areas. This section develops such a map. The subsequent section uses this map to determine where and in what direction national policy strategies and the scope of multilateral rules and disciplines could be altered to increase the effectiveness of national policies for attaining growth and development targets in an integrating economy. As already mentioned in the introduction, this mapping is based on what Stiglitz et al. (2006) call the "heterodox perspective" because the integration strategy proposed from this perspective implies a much more proactive role of economic policies than, for example, World Bank (2005), the Sachs Report or the Spence Report. Hence, the findings of this paper may be considered the outcome of an extreme case scenario.

\footnotetext{
${ }^{10}$ While recognizing that there are broader concepts of development, this paper is limited to a focus on longer-term economic growth.
} 
Some of these instrument-target relationships are controversial - as are those of alternative perspectives - and their developmental effects clearly depend on country- and time-specific factors. Thus, they should not be seen as a blueprint for development strategies but rather as a framework that identifies objectives and spells out how policy instruments can be deployed to attain them; this, in turn, allows determining which and in what way specific instrumenttarget relationships are affected by de facto and de jure integration.

The heterodox perspective criticizes the instrument-target relationships of the reform agenda that many developing countries pursued during the 1980s and 1990s as being too narrowly focused on monetary stabilization, emphasizing intermediate targets (monetary stabilisation) instead of final ones, and using too few instruments (mainly monetary and fiscal policies) due to an excessive focus on price stability and allocative efficiency as the key conditions for economic growth. It argues that relying on monetary stabilization and efficient use of resources ignores the interrelationship between stabilization and growth, as well as the potential adverse impacts of international market forces - unleashed through broad-based trade and financial integration - on stabilization and growth. Furthermore, it criticizes this approach for considering its policy agenda as a blueprint, with insufficient attention given to country-specific conditions. In this sense, the heterodox perspective does not prescribe a different, yet still globally applicable blueprint. Rather, it represents an alternative perspective on policy targets and instrument-target relationships whose operational details and requisite reform prescriptions will vary across countries depending on local economic and institutional conditions.

The heterodox perspective sees the dynamics of production structures as the engine of growth and development. Hence, governments are to pursue macroeconomic policies that combine stabilization with growth promotion, and adopt trade and other structural policies that encourage investment (both domestic and foreign) which generates new products and new production processes and facilitates the creation of linkages among domestic firms and sectors. It argues that financial liberalization can rapidly give rise to speculative short-term financial flows through which events on international markets and policies adopted by other countries can have a disruptive effect on domestic policies. Hence, there is a strong emphasis on proactive macroeconomic and structural policies to stimulate productive investment, move an economy towards high-productivity sectors and activities, and reduce its vulnerability to potential adverse effects from financial liberalization. While policies should aim to achieve efficiency gains, they are considered unlikely to spur growth unless they also strengthen incentives for innovative investment and address market and government failures that undercut efforts to accumulate capital and boost productivity.

Figure 1 suggests a map of instrument-target relationships that aim at maximizing the effectiveness of domestic policy instruments in attaining sustained real income growth, structural change and technological upgrading; section (iii) of the following narrative discusses how multilateral rules and disciplines can support this maximization effort.

It is clear that the map cannot fully reflect the complexity of development policies. For example, trade-offs between instruments and/or targets can have important effects on outcomes, but this is not reflected here. While the map helps to clarify the specific purpose and potential contribution of each instrument, it needs to remain at a rather general level. Individual countries will need to calibrate these broad instrument-target assignments to their specific economic and social conditions, national preferences and institutional set-ups. Combined with the subsequent narrative, the map is, nonetheless, useful in providing broad indications on a set of policy instruments and targets available to conduct a consistent and coordinated development strategy that aims at sustained real income growth, structural change and technological upgrading. The figure reflects the primary link between instruments (in squares) and intermediate targets, as well as quantitative measures of these targets, (encircled) through double-line arrows, while single-line arrows indicate indirect links. Thick arrows 
mark links between intermediate targets and the ultimate targets of sustained real income growth, structural change and technological upgrading (encircled bold).

Figure 1

INSTRUMENT-TARGET RELATIONSHIPS FROM A HETERODOX PERSPECTIVE

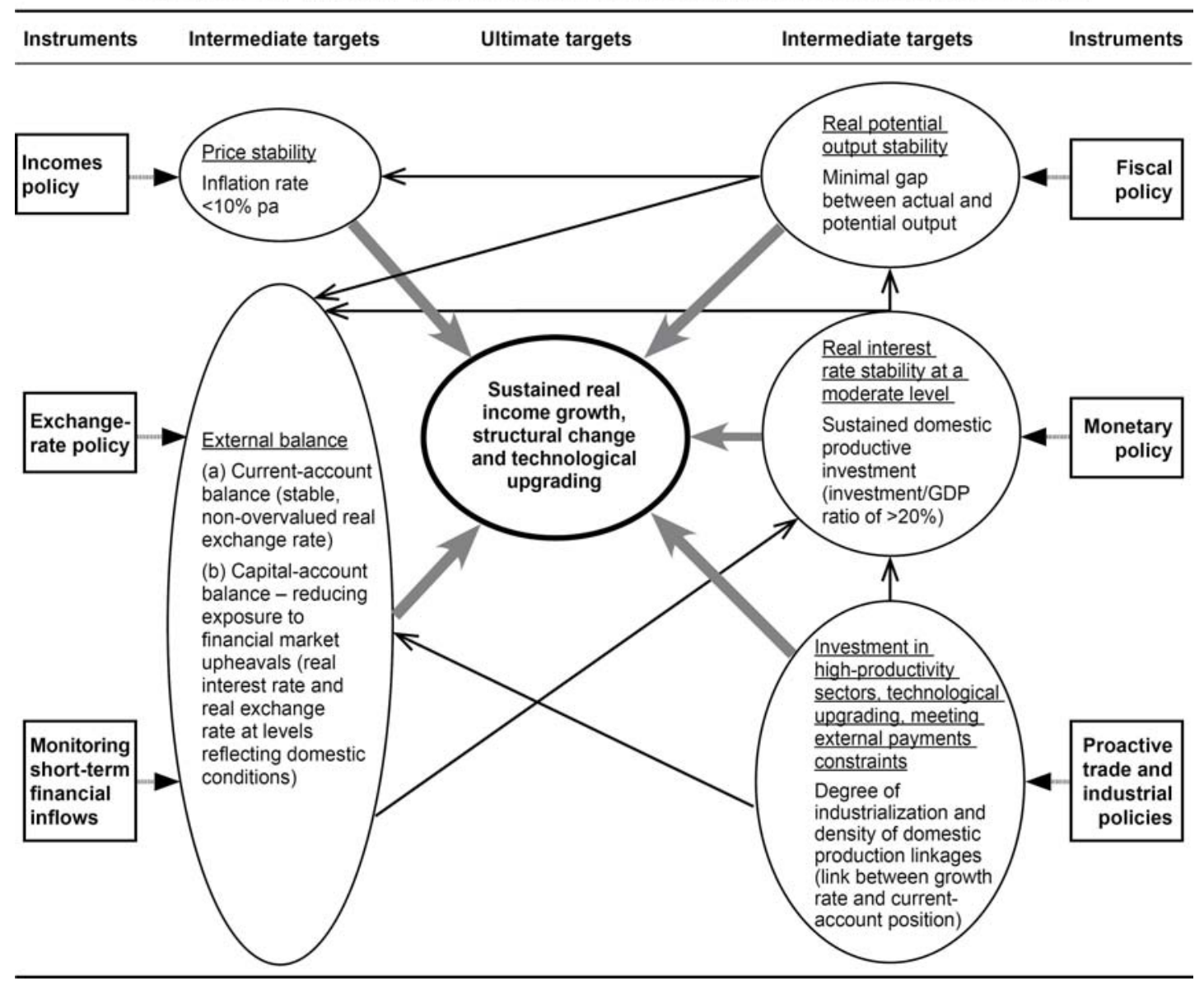

\section{A. Macroeconomic and exchange-rate policies}

The heterodox perspective considers macroeconomic stabilization and growth policies to be closely interrelated. On the one hand, the monetary and fiscal policy mix influences the behaviour of real interest rates, exchange rates, output, wages and asset prices, which in turn strongly influences investment and savings decisions, as well as the international competitiveness of a country's enterprises. On the other hand, aggregate income growth fosters household savings and, through the automatic stabilizers, fiscal accounts, as well as productivity growth that enables non-inflationary wage growth. Hence, in order to be conducive to productive investment and income growth, macroeconomic stabilization should be targeted at real, rather than monetary, variables (such as real output, real interest and real exchange rates) and should aim at encouraging and supporting the creation and expansion of internationally competitive productive capacity.

Stabilization polices that pay insufficient attention to this broad view of macroeconomic stability and the respective trade-offs (e.g. between maximizing anti-inflationary measures and minimizing output losses) may fail to generate rapid economic growth. Indeed, macroeconomic stabilization with a narrow focus on monetary variables, combined with broad-based liberalization, may lead to a peculiar combination of macroeconomic prices 
(i.e. high real interest and strong real exchange rates) that fail to increase investment, introduce new technologies and expand exports.

The heterodox perspective sees fiscal stabilization is a key instrument for achieving overall macroeconomic stability, which in turn provides the foundation for price and exchange-rate stabilization. It defines the fiscal anchor (i.e. the fiscal policy target that ensures a sustainable and solvency-preserving fiscal policy) in terms of structural balances, and recommends basing fiscal programming on a multi-year framework that uses the ratio of fiscal expenditure to potential aggregate income. ${ }^{11}$ From this perspective, using potential output as a target measure keeps inflation and exchange-rate expectations under control, and provides macroeconomic stability by eliminating the unwanted effects of cyclical fluctuations on the programming and execution of fiscal spending. Overall, using potential output as a target measure is seen as helping policymakers develop a mix of macroeconomic disciplines and flexibility to react to imbalances in the real economy arising from a significant gap between potential and actual aggregate income or from unexpected changes in the business cycle. ${ }^{12}$

Tax design and expenditure composition are important transmission channels of the growth impact of fiscal policy. Ensuring that the tax system does not distort incentives and shifting the composition of expenditures towards more productive uses enhances the growth stimulus of fiscal policy at any deficit level. Growth-enhancing fiscal expenditure is usually seen as comprising capital expenditure, as well as spending on education, health, and transport and communication infrastructure (e.g. Adam and Bevan, 2005). Prioritizing among these spending targets to maximize the economic return on government spending will depend on country-specific growth constraints.

The heterodox perspective does not view low inflation itself as a policy target because, owing to uncertainty about the often only weak link between inflation and real variables, it is preferable to focus directly on observable real variables. International integration further enhances this uncertainty because the prices of many items produced or consumed domestically are increasingly determined by foreign demand and supply factors. Hence, inflation becomes less responsive to output gap fluctuations, and monetary policy needs to be less restrictive to meet a certain inflation target (Mody and Ohnsorge, 2007). Moreover, moderate inflation rates are considered unlikely to impede economic growth. According to a wide range of studies, inflation is detrimental to growth only if it is in excess of a certain threshold. While there is no agreement on the level of that threshold, it is often considered to be around 10 per cent per annum. ${ }^{13}$

In addition to the stabilization effects stemming from the monetary and fiscal policy mix, the heterodox perspective recommends to achieve price stability through an incomes policy (i.e. controlling wage growth as a source of cost inflation by coercing or persuading employers

\footnotetext{
11 Potential GDP is the level of output that an economy can produce at a constant inflation rate. Potential output is country- and time-specific as it depends on the capital stock, the potential labour force (which depends on demographic factors and participation rates), the non-accelerating wage rate of unemployment (NAWRU) and the level of labour productivity.

12 Moreover, public revenue stabilization funds pertaining to temporary income from both taxes and raw material exports are an important component of a countercyclical policy framework. They help generate fiscal surpluses in boom periods and mitigate fiscal restraint during downswings.

${ }^{13}$ Khan and Senhadji (2001) indicate a threshold of 11-12 per cent per annum for developing countries; they also discuss the findings of earlier studies which mostly found higher threshold levels. The rationale for allowing moderate inflation rates is also based on the strongly adverse economic impact of deflation and the fact that monetary policy is ineffective when an economy is in deflation. Moreover, there are important trade-offs between rapid disinflation and growth, because with rapidly falling inflation high nominal interest rates quickly translate into high real interest rates that discourage productive investment and limit growth.
} 
and employees to restrict their price and wage increases within a given level of overall productivity growth). The easiest way to apply incomes policy is through wage and price controls or, in a less interventionist way, by setting wages through centralized collective bargaining, where wage agreements are monitored through tripartite agreements between the government and employees' and employers' associations. Productivity growth in domestic production of consumer goods and, more generally, low real prices for wage goods also contribute to curbing excessive wage cost increases and spurring growth, as they allow real wages to rise without impeding investment and international competitiveness.

With incomes and fiscal policies being the main instruments to control inflation, monetary policy can be targeted at economic growth. The following are the immediate targets of monetary policy from a heterodox perspective: maintaining interest rates at levels that provide domestic credit on terms and conditions that offer appropriate incentives for productive investment; maintaining a competitive and stable real exchange rate; and ensuring the development and stability of the domestic financial system. ${ }^{14}$ At the same time, balance-sheet vulnerabilities (e.g. caused by liability dollarization and maturity mismatches) must be minimized to foster financial sector stability. Financial development, supported by banking and non-bank financial regulations, safeguards most domestic control over policy variables if it creates and consolidates domestic-currency-denominated intermediation instruments (e.g. bank loans, corporate bonds, securitized assets) that facilitate productive investment.

The heterodox perspective argues that the volatility and pro-cyclical character of short-term capital flows requires the prudential management of such capital flows in order to preserve macroeconomic stability and allow policymakers to use restrictive monetary policy during economic upswings and avoid excessively contractionary policies during slowdowns. The key objective of managing short-term capital flows is preventing the cumulative build-up of foreign liabilities that can be easily reversed; that is, preventing cyclical upturns in external financing from triggering excessive increases in external credit to the domestic private sector, preventing capital inflows from causing real exchange rate overvaluation, and controlling mismatches in the currency denomination of assets and liabilities in the domestic financial sector. Related instruments can be indirect (e.g. prudential regulations) or direct (e.g. reserve requirements or taxes on external financing, direct regulation of portfolio flows). Measures adopted in the 1990s by Chile and Colombia are often cited as examples of direct instruments (Epstein, Grabel and Jomo, 2004). ${ }^{15}$ However, in order to make the use of these instruments effective, sustainable monetary and fiscal policies must underpin the prudential management of short-term capital inflows.

In terms of choosing the exchange-rate regime, the heterodox perspective advises against adopting so-called "corner solutions" (i.e. fixed pegs or full floating). In particular, it opposes use of the exchange rate as an instrument for disinflation. It sees maintaining a sustainable current-account position and stability of the real exchange rate at a level that preserves domestic firms' international competitiveness as the main targets of exchange-rate policy. An

\footnotetext{
${ }^{14}$ Interest rate policy involves a number of trade-offs. It will affect investment only to the extent that investment is debt-financed and only when investors see profitable investment opportunities. Moreover, controlling exchange-rate fluctuations through interest-rate policy is difficult in financially integrated economies because domestic interest rates become heavily exposed to pro-cyclical and volatile short-term international financial flows. This in turn risks creating boom and bust cycles in domestic asset prices.

${ }^{15}$ The IMF Articles of Agreement allow such controls. Article VI section 3 (Controls of Capital Transfers) states "Members may exercise such controls as are necessary to regulate international capital movements ...”. IMF policy advice may become more favourable towards controlling capital flows. According to the Independent Evaluation Office (2005: 6) of the IMF “the IMF has learned over time on capital account issues" and "the new paradigm ... acknowledges the usefulness of capital controls under certain conditions, particularly controls on inflows”. So far, this has not yet been consistently reflected in policy advice because of "the lack of a clear position by the institution".
} 
overvaluation and excessive volatility of the real exchange rate are to be avoided in order to support export growth with a view to expanding investment and output. While the real exchange rate is a relative price, and hence not under the direct control of policymakers, it can be influenced by fiscal, monetary, income and capital-account policies, as well as by foreignexchange interventions (Eichengreen, 2007; Rodrik, 2008). ${ }^{16}$ Choosing soft pegs or managed floating as an exchange-rate regime facilitates achievement of these policy targets. ${ }^{17}$

\section{B. Integration and structural policies}

Regarding the objective of de facto integration, the heterodox perspective emphasizes support for the development and continuous upgrading of productive capacity while meeting intertemporal budget constraints, rather than narrowly aiming at efficiency gains from aligning domestic to international prices. This is to be achieved through strategic integration, which compared to rapid and broad-based liberalization is a more measured, selective and policy-driven strategy. Strategic trade integration emphasizes the mutually reinforcing links between trade, investment and growth. The pace and pattern of trade integration should ensure that import liberalization does not cause balance-of-payments problems, and that export earnings translate into increased investment. These effects combined are seen to improve a country's manufacturing capacity and productivity, while avoiding growing dependence on external capital.

The heterodox perspective considers the creation of the technological capability to competitively produce goods previously purchased abroad to be a natural feature of economic development. However, due to the multitude of information and coordination failures associated with investment and productivity growth, relying on the incentives generated from allocative efficiency may not suffice (Rodrik, 2004). Rather, the heterodox perspective emphasizes the need for proactive trade and industrial policies to foster nascent industrial activity and promote technology transfer and adaptation. Such national policies are not meant to be inward-looking, protectionist mechanisms to support industries in which production and employment are threatened by foreign competitors that have successfully upgraded their production. Rather, they aim to strengthen productive investment. The way in which production might be considered for policy support and for how long depends on many factors that change in the course of economic development. ${ }^{18}$

The range of instruments designed to attain such targets include performance requirements for foreign investors, subsidies conditional on export performance to encourage international competitiveness of nascent domestic manufacturing, flexible use of compulsory licensing for the domestic use of protected foreign intellectual property, a flexible import tariff policy that modulates applied tariffs on particular manufacturing sectors around a stable average level, and many more.

Rodrik (2004) argues that the aim of proactive trade and industrial policies is not to pick winners, but to identify and discipline underperforming firms. Thus, the establishment of clear operational goals, time horizons and sunset clauses, as well as the adoption and effective

\footnotetext{
${ }^{16}$ Regarding the question of the real exchange rate as a development policy tool, Eichengreen (2007: $23 ; 10)$ notes that it "is best thought of as a facilitating condition: keeping it at competitive levels and avoiding excessive volatility facilitate efforts to capitalize on these fundamentals” and, more generally asserts, "it is a useful summary indicator of the growth-friendly or unfriendly stance of economic policy”.

17 As outlined by Bradford (2005: 5-6), choosing managed exchange-rate regimes, combined with selective capital controls, also allows for some monetary policy autonomy. Thus, it avoids the impossible trinity, i.e. the impossibility to have a fixed exchange rate, a completely open capital account and full monetary policy autonomy at the same time.

${ }^{18}$ For detailed discussion see, for example, Rodrik (2004) and UNCTAD (2006: 152-166).
} 
monitoring of observable performance criteria is critical to the success of this strategy. In a sense, the enforcement of performance requirements, particularly those related to productivity gains as imposed by the disciplines of the international market, represents the "stick" that complements the "carrot" provided by the creation of rents from productivity-enhancing investment supported by temporary subsidies and protection. It is by constraining the use of such trade-related performance requirements that, from a heterodox perspective, the UR agreements most seriously reduce developing countries' policy space.

\section{Institutions}

Regarding institutional arrangements, the heterodox perspective emphasizes that government action is a strategic complement to markets. Juxtaposing government and markets, or government failures and market failures, would be misleading. Rather, institutions must introduce corrective measures against both market failure and government failure. Governments need to be made accountable, not bypassed. Institutional change should aim at improving checks and balances on government discretion, addressing information and coordination externalities, monitoring instrument-target relationships, and managing reciprocal control mechanisms designed to minimize abuse of economic rents that are inherent to the dynamics of structural change in production and trade. Strategic collaboration between the government, business organizations and institutions of learning and innovation is an important instrument to this end.

The heterodox perspective sees the main target of de jure integration as reducing exposure to adverse external effects, including protection from beggar-thy-neighbour policies adopted by other countries. This target is closely related to the overall rationale for multilateral rules and commitments, discussed in section 2 above.

The heterodox perspective values the core principles of the multilateral trading regime, namely reciprocity and non-discrimination, as reflected in the most-favoured nation rule. It supports the WTO in its primary function to provide negotiated, binding and enforceable rules, the key benefits of which are the resulting certainty and predictability of international trade. Upholding such a system based on multilaterally agreed rules outlaws beggar-thyneighbour type trade policies. The heterodox perspective raises concern from a policy-spacerelated point of view about the net benefit of bilateral or regional North-South agreements because such agreements require developing countries to exchange expected short-term benefits from greater export market access and FDI inflows for constraints on the use of certain policy instruments including in areas that are no longer (government spending, competition policy, investment) or never have been (environmental and labour standards, capital account issues) at issue in WTO negotiations (Shadlen, 2005).

\section{NATIONAL AND INTERNATIONAL MEASURES TO ENLARGE POLICY SPACE}

Based on the mapping of instrument-target relationships in figure 1, table 1 links broad policy areas to levels of policy-making. The table aims at indicating where policymakers could take measures to use existing policy space more effectively and further enlarge their current policy space without opting out of international commitments. The basic point of the table is to show that such measures would imply a reassessment of instrument-target assignments at the national level and a rationalization of multilateral rules and disciplines at the international level. This rationalization would entail tighter, rather than looser, multilateral disciplines in money and finance. It would aim in particular to control wide deviations from underlying conditions of the nominal exchange rates among those countries that have the greatest impact on international monetary and financial stability. 
Table 1

CONSTRAINTS ON DEVELOPING COUNTRIES' POLICY SPACE AND MEASURES FOR ITS ENLARGEMENT

\begin{tabular}{|c|c|c|c|}
\hline & \multirow{2}{*}{$\begin{array}{c}\text { Sources of current } \\
\text { restrictions on national } \\
\text { policy space }\end{array}$} & \multicolumn{2}{|c|}{$\begin{array}{l}\text { Measures for preserving or enlarging existing policy space } \\
\text { without opting out of existing commitments }\end{array}$} \\
\hline & & National measures & International measures \\
\hline $\begin{array}{l}\text { Macroeconomic } \\
\text { policies }\end{array}$ & $\begin{array}{l}\text { De facto (particularly } \\
\text { financial) integration } \\
\text { Loan conditionality of } \\
\text { international financial } \\
\text { institutions } \\
\text { Aid conditionality of } \\
\text { donors }\end{array}$ & $\begin{array}{l}\text { Reassessment of policy } \\
\text { targets and instrument- } \\
\text { target relationships, from } \\
\text { emphasizing monetary } \\
\text { stabilization towards } \\
\text { emphasizing real economic } \\
\text { variables and the } \\
\text { interrelationship between } \\
\text { stabilization and growth- } \\
\text { enhancing policies. }\end{array}$ & $\begin{array}{l}\text { Tighter multilateral } \\
\text { disciplines over } \\
\text { macroeconomic and } \\
\text { exchange-rate policies of } \\
\text { countries that have the } \\
\text { greatest impact on global } \\
\text { monetary and financial } \\
\text { stability. Better } \\
\text { macroeconomic and } \\
\text { exchange-rate policy } \\
\text { coordination between key } \\
\text { currency countries. Regional } \\
\text { monetary and financial } \\
\text { cooperation among } \\
\text { developing countries. }\end{array}$ \\
\hline \multirow[t]{2}{*}{$\begin{array}{l}\text { Structural } \\
\text { policies: mainly } \\
\text { trade and } \\
\text { industrial }\end{array}$} & $\begin{array}{l}\text { De jure trade } \\
\text { integration through } \\
\text { both multilateral } \\
\text { agreements, and in } \\
\text { particular bilateral and } \\
\text { regional North-South } \\
\text { agreements. }\end{array}$ & $\begin{array}{l}\text { Reassessment of policy } \\
\text { targets and instrument-target } \\
\text { relationships, from } \\
\text { emphasizing maximization of } \\
\text { export market access and } \\
\text { FDI inflows towards } \\
\text { maximizing creation of } \\
\text { domestic value added and } \\
\text { linkages. }\end{array}$ & $\begin{array}{l}\text { Avoiding further tightening of } \\
\text { WTO disciplines on } \\
\text { developing countries' } \\
\text { industrialization strategies } \\
\text { and of multilateralisation of } \\
\text { WTO-plus rules on } \\
\text { intellectual property rights, } \\
\text { investment, government } \\
\text { procurement, etc. }\end{array}$ \\
\hline & & $\begin{array}{l}\text { Avoidance of additional } \\
\text { constraints from bilateral } \\
\text { trade and investment } \\
\text { agreements. }\end{array}$ & $\begin{array}{l}\text { Tighter WTO disciplines on } \\
\text { developed-country use of } \\
\text { trade contingency measures } \\
\text { (e.g. zeroing in antidumping) } \\
\text { and agricultural support and } \\
\text { protection. }\end{array}$ \\
\hline Institutions & $\begin{array}{l}\text { Developed countries' } \\
\text { dominance of } \\
\text { multilateral norm } \\
\text { setting and their use of } \\
\text { their own institutional } \\
\text { settings as a blueprint } \\
\text { for national institutions } \\
\text { in developing } \\
\text { countries. }\end{array}$ & $\begin{array}{l}\text { Reorientation from } \\
\text { efficiency-enhancing to } \\
\text { growth-enhancing } \\
\text { institutions. }\end{array}$ & $\begin{array}{l}\text { Reassessment of global } \\
\text { economic governance } \\
\text { structure to allow developing } \\
\text { countries to become } \\
\text { proactive norm setters. }\end{array}$ \\
\hline
\end{tabular}

De jure constraints on developing countries' policy space are the most pronounced for structural policies. ${ }^{19}$ The UR agreements account for some of this restriction. Nevertheless, these agreements have left some policy space. ${ }^{20}$ While the Agreement on Trade-related Aspects of Intellectual Property Rights (TRIPS) risks pre-empting or stifling countries' ability to develop domestic technological capabilities, it does allow flexible use of compulsory licensing. The Agreement on Trade-related Investment Measures (TRIMS) makes it difficult to link investment support to export-related disciplines aimed at withdrawing support from producers that do not achieve international competitiveness within a pre-defined period of

${ }^{19}$ See Gallagher (2005) for a detailed discussion of the issues addressed in this paragraph. It should also be recognized that there are many informal constraints; for example, aid-dependent countries often lack the confidence to carry out policies that might conflict with the interests of donors.

${ }^{20}$ This is true particularly for least developed countries, for which transition periods have been extended, for example for TRIPS until at least 2016 and for TRIMS until at least 2020. 
time. But FDI regulating measures that do not violate national treatment or impose quantitative restrictions continue to be consistent with WTO rules. The Agreement on Subsidies and Countervailing Measures implies a significant tightening of disciplines, but some subsidies have been tacitly allowed, with neither developed nor developing countries challenging them. There is disagreement as to whether the remaining permitted subsidies are sufficient to allow support for industrial development support, but it is clear that fiscal cost is a major constraint on many developing countries' use of such subsidies. Pursuing a flexible tariff policy remains possible for many developing countries, although this potential has remained largely unexploited. In this respect, possible constraints on flexible tariff policies resulting from the Doha Round negotiations might reduce potential, but not current, policy space. Developing countries appear to accord greater importance to securing constraints on developed countries' agricultural policy space than to maintaining their own policy space for industrial tariffs. Meanwhile, North-South economic integration agreements have resulted in further de jure constraints, as discussed in the preceding section.

It is through supposedly sovereign decision that developing-country policymakers sign on to the commitments of international trade agreements that reduce de jure policy space. This may partly reflect some preference by policymakers for short-term benefits over autonomy in deciding on their long-term policy options. ${ }^{21}$ But different degrees of influence between developed and developing countries on globalization trends and global economic governance often confront policymakers with difficult trade-offs. Regarding the commitments stemming from the UR agreements, Finger and Nogues (2002) note that at the end of the UR, developing countries were faced with the choice of accepting what was proposed or risk being marginalized in the international trade regime. ${ }^{22}$ As for engagement in North-South integration agreements, Baldwin (1997) notes a domino effect: existing North-South preferential agreements tempt non-members to join so as not to lose out on access to sizeable export markets and sources of FDI. Hence, while engaging in international commitments may be a "sovereign" decision, there is often little alternative.

Preserving the remaining multilateral de jure policy space for developing countries to undertake structural policies implies that, at the international level, moves to multilateralize bilateral and regional trade agreements should not extend to their WTO-plus commitments. It also implies that a potential further tightening of WTO rules should emphasize greater disciplines on developed countries' use of trade contingency measures (e.g. the practice of zeroing in anti-dumping) and of agricultural support and protection. At the national level, it would imply a reassessment of the relative benefits stemming from greater export market access and FDI inflows on the one hand, and flexibilities in policies designed to maximize the creation of domestic linkages and value added on the other.

In spite of exposing the domestic economy to a number of adverse influences originating in international markets, de facto international economic integration preserves significant national policy space. As outlined in the previous section, fully exploiting this policy space requires a reassessment of policy targets and instrument-target relationships at the national level. Such a reassessment, including the use of a greater number of policy instruments, would aim at pursuing more pro-active macroeconomic and structural policies while reducing

\footnotetext{
${ }^{21}$ Depending on the relative size of the costs and benefits involved, this may not imply an overall negative net benefit, particularly to the extent that policymakers can denounce such agreements after benefits have started to accrue while costs have not yet set in, or because they were not intending to use the foregone policy space.

${ }^{22}$ According to Finger and Nogues (2002: 334), influential developed countries had announced that they would withdraw from the General Agreement on Tariffs and Trade (GATT) as soon as the WTO came into existence. This implied that a country that did not accept the "grand bargain" of the UR agreements would not have enjoyed protection from discriminatory treatment, either from the new WTO or the old GATT rules and regulations.
} 
the vulnerability of the domestic economy to adverse spillover effects of international monetary and financial disturbances.

The developmental effectiveness of macroeconomic and structural policies would be strengthened by a reorientation of developing countries' institutional arrangements from efficiency-enhancing towards growth-enhancing institutions (Khan, 2007), in particular by deploying reciprocal control mechanisms for the effective management of economic rents associated with proactive trade and industrial policies.

The effectiveness of reassessing policy targets and instrument-target relationships at the national level will be strengthened in particular by adopting appropriate measures at the international level aimed at tackling the root causes of international monetary and financial disturbances. Unlike the multilateral trading regime, current monetary and financial arrangements are not organized around a multilaterally negotiated set of rules that would be binding and enforceable for all participants. Existing rules do not seem to offer appropriate instruments for tackling major global financial problems such as exchange rate volatility, sizeable and prolonged current-account imbalances, and the dominance of short-term financial flows over long-term ones.

The Bretton Woods system contained multilateral disciplines to control two main channels of exchange-rate instability (Akyüz, 2007). First, restrictions over short-term arbitrage flows sought to limit interest-rate arbitrage, and hence the scope of markets to generate unexpected and erratic exchange-rate movements. Second, the exchange-rate arrangement implied obligations for countries to maintain their exchange rates within a narrow range of agreed par values, thus preventing beggar-thy-neighbour policies based on competitive devaluations; but it also allowed them to change their par values under fundamental disequilibrium. These institutional arrangements allowed the Bretton Woods system to maintain a balance between national policy autonomy on the one hand and multilateral disciplines on the other. Sacrificing formal monetary autonomy was rewarded by stability in the financial markets and better foresight in international trade and in related decisions concerning investment in fixed capital.

Following the demise of the Bretton Woods system, strengthened surveillance over national policies in IMF Article IV consultations has sought to compensate for the lack of multilateral disciplines on exchange-rate policies. However, such disciplines generally have not extended to those countries whose policies have the greatest impact on global monetary and financial stability. Given that the IMF can exert meaningful disciplines only through conditionality built into loan agreements, its policy oversight is confined primarily to its poorest members, who need to draw on its resources because of their lack of access to private sources of finance and, occasionally, to emerging market economies experiencing currency and financial crises. However, IMF surveillance has been unable to prevent exchange-rate gyrations and wide divergences from underlying conditions, unsustainable balance-of-payments positions, volatile and often speculative short-term capital flows and recurrent financial crises.

While desirable, there is currently little prospect for tightening multilateral rules similar to Bretton-Woods-type multilateral disciplines in monetary and financial matters. Macroeconomic policy coordination among those countries that have the greatest impact on international monetary and financial stability could attain the same objective on a more voluntary basis. By aiming at maintaining real exchange rate stability among the key currencies, it would help guide expectations that underlie international capital flows and hence, reduce the likelihood of unsustainable interest rate differentials and divergences of exchange rate from underlying conditions (e.g. Bergsten, Davanne and Jacquet, 1999). However, given current disagreement about the root causes, sustainability, need for and type of appropriate measures for the unwinding of global imbalances, the prospect for such a solution appears to be weak. 
Strengthened South-South regional cooperation in monetary and financial matters may prove to be a more feasible alternative for developing countries to reduce their exposure to adverse spillover effects, negative externalities from other countries' beggar-thy-neighbour policies, and short-term interest-rate arbitrage by financial speculators (UNCTAD, 2007). Greater regional financial integration, for example through bond and loan issuance in regional currencies, could make intraregional financial intermediation more effective and efficient, facilitate access to long-term financing, stabilize financial prices, and reduce balance sheet currency mismatches, thus promoting regional financial stability. Swap agreements, reserve pooling and regional exchange-rate mechanisms, combined with greater macroeconomic and financial policy coordination, could secure stability and orderly adjustments of intra-regional exchange rates. And regional surveillance over macroeconomic and financial market conditions could provide early warning signals. The European experience holds useful lessons in this respect, but given its geographic and time-bound specificities, it cannot be considered a blueprint for application by developing countries.

Since developing countries have gradually acquired greater weight in the global economic arena, they have a stronger need for a commensurate voice and representation in multilateral financial institutions. To strengthen the legitimacy of these institutions, key decisions need to be based on voluntary, full and equal participation, with an appropriate level of consensus. Achieving this will require a reassessment of the global economic governance structure with a view to allowing developing countries to become proactive norm setters.

\section{CONCLUSIONS}

This paper has sought to examine how developing countries can effectively use their existing national policy space, and even enlarge it, without opting out of their international commitments. This examination leads to five main conclusions: (i) the tension between international integration and national policy flexibility is affected by several forces that pull in opposite directions; (ii) globalization and the resulting rise in economic interdependence, both across countries and policy areas, as well as de jure restrictions to which developing countries have signed onto through supposedly sovereign decisions, have altered the degree of freedom for national policymakers to design and implement effective national economic policies; (iii) whether international integration and regulation on balance increase or reduce the degrees of freedom in national policy-making depends on what type of policy instrument is affected, by how much and in what direction - the balance is likely to differ across countries and types of integration; (iv) there remains considerable policy autonomy in macroeconomic and exchange-rate policies. This is particularly true for the increasing number of developing countries that have a strong external position - either because of substantial revenues from commodity exports or a deliberate accumulation of foreign-exchange reserves - and that are no longer (or never have been) subject to IFI or donor conditionality; and (v) effectively using existing policy space and enlarging it without opting out of international commitments requires action at both the national and international levels.

At the national level, effectively using and enlarging existing national policy space requires a reassessment of policy targets and instrument-target relationships with the overall objective of employing instruments that allow the combining of stabilization with growth-enhancing policies. This entails an emphasis on real economic variables, rather than monetary stabilization, choosing an intermediate exchange-rate regime, rather than fixed pegs or full floating, and managing short-term financial inflows, rather than aiming at full capital-account convertibility. Within a broader outward-oriented development strategy, structural policies would use a wide range of fiscal and regulatory policies aimed at achieving high investment rates, technological upgrading and structural change. Coherence between macroeconomic and structural policies is crucial. A macroeconomic policy stance that leads to high domestic interest rates and an overvalued exchange rate is not conducive to investment that can boost 
productivity growth and improve the international competitiveness of domestic enterprises, even when structural policies provide incentives for such investment. Macroeconomic and structural policies would need to be supported by institutional arrangements which address information and coordination failures that risk undermining entrepreneurial decision-making. Such arrangements would also need to improve checks and balances on the use of government discretion.

Appropriate action at the international level to reduce the exposure of developing countries to adverse spillover effects, negative externalities from other countries' beggar-thy-neighbour policies, and short-term interest-rate arbitrage of financial speculators would significantly facilitate national efforts to pursue such macroeconomic and structural policies effectively. The best way for achieving this would be to extend the scope of multilateral rules and disciplines in the monetary and financial area with a view to curbing speculative short-term financial flows and exchange-rate gyrations and controlling wide divergence from underlying conditions of the exchange rates of those countries that have the greatest impact on global monetary and financial stability. Given the limited prospects for such a multilateral solution in the near future, strengthened regional cooperation in monetary and financial matters may be a feasible alternative. Both these solutions would bring about greater coherence between the international trading and financial systems so that they reinforce, rather than undermine and destabilize, one another.

The outlined national and international measures result from an examination of constraints on developing countries' policy space and measures for its enlargement from a heterodox perspective of development policy making. Accordingly, perspectives that give less importance to proactive macroeconomic and sectoral policies, such as World Bank (2005) or the Sachs and the Spence Reports, would argue that there is less of a need for moving away from macroeconomic and exchange-rate policy assignments of the 1980s and 1990s, and that there is less need for strengthening multilateral rules and disciplines in the area of money and finance. 


\section{REFERENCES}

Abugattas L and Paus E (2006). Policy space for a capability-centered development strategy for Latin America. Available at: http://www.mtholyoke.edu/ epaus/paus-abugattas.pdf.

Adam CS and Bevan DL (2005). Fiscal deficits and growth in developing countries. Journal of Public Economics, 89(4): 571-597.

Akyüz Y (2007). Global Rules and Markets: Constraints over Policy Autonomy in Developing Countries. Global Economy Series No. 10. Penang, Third World Network.

Baldwin RE (1997). The causes of regionalism. World Economy, 20(7): 865-888.

Bergsten CF, Davanne O and Jacquet P (1999). The case for joint management of exchange rate flexibility. Working Paper 99:9. Washington, DC, Institute for International Economics.

Bradford CI (2005). Prioritizing Economic Growth: Enhancing Macroeconomic Policy Choice. G-24 Discussion Paper No. 37. New York and Geneva, UNCTAD, November.

Brown AG and Stern RM (2006). Global market integration and national sovereignty. World Economy, 29(3): 257-279.

Bryant RC (1980). Money and Monetary Policy in Interdependent Nations. Washington, DC, The Brookings Institution.

Commission on Growth and Development (2008). The Growth Report: Strategies for Sustained Growth and Inclusive Development. Washington, DC, World Bank.

Cooper RN (1968). The Economics of Interdependence: Economic Policy in the Atlantic Community. New York, McGraw Hill for the Council on Foreign Relations.

DiCaprio A and Gallagher KP (2006). The WTO and the shrinking of development space: How big is the bite? Journal of World Investment and Trade, 7(5): 781-803.

Eichengreen B (2007). The real exchange rate and economic growth. Available at: http://emlab.berkeley.edu/users/eichengr/real_exchange_rate.pdf.

Epstein G, Grabel I and Jomo KS (2004). Capital management techniques in developing countries: An assessment of experiences from the 1990s and lessons for the future. G-24 Discussion Paper No. 27. New York and Geneva, UNCTAD, March.

Finger JM and Nogues JJ (2002). The unbalanced Uruguay Round outcome: The new areas in future WTO negotiations. World Economy, 25(3): 321-340.

Gallagher KP ed. (2005). Putting Development First: The Importance of Policy Space in the WTO and International Financial Institutions. London and New York, Zed Books.

Hamwey RM (2005). Expanding national policy space for development: Why the multilateral trading system must change. Working Paper 25. Geneva, South Centre.

Hausmann R, Klinger B and Wagner R (2008). Doing growth diagnostics in practice: A 'mindbook'. Working Paper 177. Harvard University, Center for International Development.

Hausmann R and D Rodrik (2003). Economic development as self discovery. Journal of Development Economics, 72(2): 603-633.

Independent Evaluation Office (2005). The IMF's Approach to Capital Account Liberalization. Washington, DC, International Monetary Fund.

Khan MH (2007). Governance, economic growth and development since the 1960s. DESA Working Paper 54. United Nations, New York.

Khan MS and Senhadji AS (2001). Threshold effects in the relationship between inflation and growth. IMF Staff Papers, 48(1):1-21.

Kumar N and Gallagher KP (2007). Relevance of 'policy space' for development: Implications for multilateral trade negotiations. RIS Discussion Paper No. 120. New Delhi.

Mody A and Ohnsorge F (2007). Can domestic policies influence inflation? Working Paper No. 07/257. Washington, DC, International Monetary Fund, November.

Rodrik D (2004). Industrial policy for the twenty-first century. Discussion Paper 4767. London, Centre for Economic Policy Research.

Rodrik D (2008). The real exchange rate and economic growth. Available at: http://www.brookings.edu/economics/bpea/ /media/Files/Programs/ES/BPEA/2008_fall_bpea _papers/2008_fall_bpea_rodrik.pdf.

Shadlen K (2005). Exchanging development for market access? Deep integration and industrial policy under multilateral and regional-bilateral trade agreements. Review of International Political Economy, 12(5): 750-775.

Stiglitz J et al. (2006). Stability with Growth: Macroeconomics, Liberalization and Development. Oxford, Oxford University Press.

Tinbergen J (1952). On the Theory of Economic Policy. Amsterdam, North Holland. 
United Nations (2007). Industrial Development for the $21^{\text {st }}$ Century: Sustainable Development Perspectives. New York, United Nations.

United Nations Millennium Project (2005). Investing in Development: A Practical Plan to Achieve the Millennium Development Goals. London and Sterling (VA), Earthscan.

UNCTAD (various issues). Trade and Development Report. United Nations publications, New York and Geneva.

Van Velthoven BCJ (1990). The applicability of the traditional theory of economic policy. Journal of Economic Surveys, 4(1): 59-88.

World Bank (2005). Economic Growth in the 1990s: Learning from a Decade of Reform. Washington, DC, World Bank. 
UNCTAD DisCuSSION PAPERS

\begin{tabular}{|c|c|c|c|}
\hline No. & Date & Author(s) & Title \\
\hline 190 & October 2008 & Martin Knoll & $\begin{array}{l}\text { Budget support: a reformed approach or old wine in } \\
\text { new skins? }\end{array}$ \\
\hline 189 & September 2008 & Martina Metzger & $\begin{array}{l}\text { Regional cooperation and integration in sub- } \\
\text { Saharan Africa }\end{array}$ \\
\hline 188 & March 2008 & Ugo Panizza & $\begin{array}{l}\text { Domestic and external public debt in developing } \\
\text { countries }\end{array}$ \\
\hline 187 & February 2008 & Michael Geiger & $\begin{array}{l}\text { Instruments of monetary policy in China and their } \\
\text { effectiveness: 1994-2006 }\end{array}$ \\
\hline 186 & January 2008 & Marwan Elkhoury & $\begin{array}{l}\text { Credit rating agencies and their potential impact } \\
\text { on developing countries }\end{array}$ \\
\hline 185 & July 2007 & Robert Howse & $\begin{array}{l}\text { The concept of odious debt in public international } \\
\text { law }\end{array}$ \\
\hline 184 & May 2007 & André Nassif & $\begin{array}{l}\text { National innovation system and macroeconomic } \\
\text { policies: Brazil and India in comparative } \\
\text { perspective }\end{array}$ \\
\hline 183 & April 2007 & Irfan ul Haque & Rethinking industrial policy \\
\hline 182 & October 2006 & Robert Rowthorn & $\begin{array}{l}\text { The renaissance of China and India: implications } \\
\text { for the advanced economies }\end{array}$ \\
\hline 181 & October 2005 & Dr. Michael Sakbani & $\begin{array}{l}\text { A re-examination of the architecture of the } \\
\text { international economic system in a global setting: } \\
\text { issues and proposals }\end{array}$ \\
\hline 180 & October 2005 & $\begin{array}{l}\text { Jörg Mayer and } \\
\text { Pilar Fajarnes }\end{array}$ & $\begin{array}{l}\text { Tripling Africa’s Primary Exports: What? How? } \\
\text { Where? }\end{array}$ \\
\hline 179 & April 2005 & S.M. Shafaeddin & $\begin{array}{l}\text { Trade liberalization and economic reform in } \\
\text { developing countries: structural change or de- } \\
\text { industrialization? }\end{array}$ \\
\hline 178 & April 2005 & Andrew Cornford & Basel II: The revised framework of June 2004 \\
\hline 177 & April 2005 & Benu Schneider & $\begin{array}{l}\text { Do global standards and codes prevent financial } \\
\text { crises? Some proposals on modifying the } \\
\text { standards-based approach }\end{array}$ \\
\hline 176 & December 2004 & Jörg Mayer & $\begin{array}{l}\text { Not totally naked: textiles and clothing trade in a } \\
\text { quota free environment }\end{array}$ \\
\hline 175 & August 2004 & S.M. Shafaeddin & $\begin{array}{l}\text { Who is the master? Who is the servant? Market or } \\
\text { Government? }\end{array}$ \\
\hline 174 & August 2004 & Jörg Mayer & $\begin{array}{l}\text { Industrialization in developing countries: some } \\
\text { evidence from a new economic geography } \\
\text { perspective }\end{array}$ \\
\hline 173 & June 2004 & Irfan ul Haque & Globalization, neoliberalism and labour \\
\hline
\end{tabular}




\begin{tabular}{|c|c|c|c|}
\hline No. & Date & Author(s) & Title \\
\hline 172 & June 2004 & Andrew J. Cornford & $\begin{array}{l}\text { The WTO negotiations on financial services: } \\
\text { current issues and future directions }\end{array}$ \\
\hline 171 & May 2004 & Andrew J. Cornford & $\begin{array}{l}\text { Variable geometry for the WTO: concepts and } \\
\text { precedents }\end{array}$ \\
\hline 170 & May 2004 & $\begin{array}{l}\text { Robert Rowthorn and } \\
\text { Ken Coutts }\end{array}$ & $\begin{array}{l}\text { De-industrialization and the balance of payments } \\
\text { in advanced economies }\end{array}$ \\
\hline 169 & April 2004 & Shigehisa Kasahara & $\begin{array}{l}\text { The flying geese paradigm: a critical study of its } \\
\text { application to East Asian regional development }\end{array}$ \\
\hline 168 & February 2004 & Alberto Gabriele & $\begin{array}{l}\text { Policy alternatives in reforming power utilities in } \\
\text { developing countries: a critical survey }\end{array}$ \\
\hline 167 & January 2004 & $\begin{array}{l}\text { Richard Kozul-Wright } \\
\text { and Paul Rayment }\end{array}$ & Globalization reloaded: an UNCTAD Perspective \\
\hline 166 & February 2003 & Jörg Mayer & $\begin{array}{l}\text { The fallacy of composition: a review of the } \\
\text { literature }\end{array}$ \\
\hline 165 & November 2002 & Yuefen Li & China's accession to WTO: exaggerated fears? \\
\hline 164 & November 2002 & $\begin{array}{l}\text { Lucas Assuncao and } \\
\text { ZhongXiang Zhang }\end{array}$ & Domestic climate change policies and the WTO \\
\hline 163 & November 2002 & A.S. Bhalla and S. Qiu & $\begin{array}{l}\text { China's WTO accession. Its impact on Chinese } \\
\text { employment }\end{array}$ \\
\hline 162 & July 2002 & $\begin{array}{l}\text { Peter Nolan and } \\
\text { Jin Zhang }\end{array}$ & $\begin{array}{l}\text { The challenge of globalization for large Chinese } \\
\text { firms }\end{array}$ \\
\hline 161 & June 2002 & $\begin{array}{l}\text { Zheng Zhihai and } \\
\text { Zhao Yumin }\end{array}$ & $\begin{array}{l}\text { China's terms of trade in manufactures, } \\
\text { 1993-2000 }\end{array}$ \\
\hline 160 & June 2002 & S.M. Shafaeddin & $\begin{array}{l}\text { The impact of China's accession to WTO on } \\
\text { exports of developing countries }\end{array}$ \\
\hline 159 & May 2002 & $\begin{array}{l}\text { Jörg Mayer, Arunas } \\
\text { Butkevicius and } \\
\text { Ali Kadri }\end{array}$ & Dynamic products in world exports \\
\hline 158 & April 2002 & $\begin{array}{l}\text { Yılmaz Akyüz and } \\
\text { Korkut Boratav }\end{array}$ & The making of the Turkish financial crisis \\
\hline 157 & September 2001 & Heiner Flassbeck & $\begin{array}{l}\text { The exchange rate: Economic policy tool or } \\
\text { market price? }\end{array}$ \\
\hline 156 & August 2001 & Andrew J. Cornford & $\begin{array}{l}\text { The Basel Committee's proposals for revised } \\
\text { capital standards: Mark } 2 \text { and the state of play }\end{array}$ \\
\hline 155 & August 2001 & Alberto Gabriele & $\begin{array}{l}\text { Science and technology policies, industrial reform } \\
\text { and technical progress in China: Can socialist } \\
\text { property rights be compatible with technological } \\
\text { catching up? }\end{array}$ \\
\hline
\end{tabular}




\begin{tabular}{|c|c|c|c|}
\hline No. & Date & Author(s) & Title \\
\hline 154 & June 2001 & Jörg Mayer & $\begin{array}{l}\text { Technology diffusion, human capital and } \\
\text { economic growth in developing countries }\end{array}$ \\
\hline 153 & December 2000 & Mehdi Shafaeddin & $\begin{array}{l}\text { Free trade or fair trade? Fallacies surrounding the } \\
\text { theories of trade liberalization and protection and } \\
\text { contradictions in international trade rules }\end{array}$ \\
\hline 152 & December 2000 & Dilip K. Das & Asian crisis: distilling critical lessons \\
\hline 151 & October 2000 & Bernard Shull & $\begin{array}{l}\text { Financial modernization legislation in the United } \\
\text { States - Background and implications }\end{array}$ \\
\hline 150 & August 2000 & Jörg Mayer & $\begin{array}{l}\text { Globalization, technology transfer and skill } \\
\text { accumulation in low-income countries }\end{array}$ \\
\hline 149 & July 2000 & Mehdi Shafaeddin & $\begin{array}{l}\text { What did Frederick List actually say? Some } \\
\text { clarifications on the infant industry argument }\end{array}$ \\
\hline 148 & April 2000 & Yılmaz Akyüz & $\begin{array}{l}\text { The debate on the international financial } \\
\text { architecture: Reforming the reformers }\end{array}$ \\
\hline 146 & February 2000 & $\begin{array}{l}\text { Manuel R. Agosin and } \\
\text { Ricardo Mayer }\end{array}$ & $\begin{array}{l}\text { Foreign investment in developing countries: } \\
\text { Does it crowd in domestic investment? }\end{array}$ \\
\hline 145 & January 2000 & $\begin{array}{l}\text { B. Andersen, } \\
\text { Z. Kozul-Wright and } \\
\text { R. Kozul-Wright }\end{array}$ & $\begin{array}{l}\text { Copyrights, competition and development: } \\
\text { The case of the music industry }\end{array}$ \\
\hline 144 & Dec. 1999 & Wei Ge & The dynamics of export-processing zones \\
\hline 143 & Nov. 1999 & $\begin{array}{l}\text { Yılmaz Akyüz and } \\
\text { Andrew Cornford }\end{array}$ & $\begin{array}{l}\text { Capital flows to developing countries and the } \\
\text { reform of the international financial system }\end{array}$ \\
\hline 142 & Nov. 1999 & $\begin{array}{l}\text { Jean-François } \\
\text { Outreville }\end{array}$ & $\begin{array}{l}\text { Financial development, human capital and } \\
\text { political stability }\end{array}$ \\
\hline 141 & May 1999 & $\begin{array}{l}\text { Lorenza Jachia and } \\
\text { Ethél Teljeur }\end{array}$ & $\begin{array}{l}\text { Free trade between South Africa and the European } \\
\text { Union - a quantitative analysis }\end{array}$ \\
\hline 140 & February 1999 & $\begin{array}{l}\text { M. Branchi, } \\
\text { A. Gabriele and } \\
\text { V. Spiezia }\end{array}$ & $\begin{array}{l}\text { Traditional agricultural exports, external } \\
\text { dependency and domestic prices policies: African } \\
\text { coffee exports in a comparative perspective }\end{array}$ \\
\hline
\end{tabular}

Copies of UNCTAD Discussion Papers may be obtained from the Publications Assistant, Macroeconomic and Development Policies Branch (MDPB), Division on Globalization and Development Strategies (DGDS), United Nations Conference on Trade and Development (UNCTAD), Palais des Nations, CH1211 Geneva 10, Switzerland (Fax no: +41(0)22 917 0274/Tel. no: +41(0)22 917 5896).

New Discussion Papers are accessible on the website at http://www.unctad.org. 
